\title{
Análise crítica à lei complementar no. 24/ 75 sob o prisma do preceito fundamental da democracia
}

\author{
João Carlos Leal Júnior ${ }^{1}$ \\ Julio Cesar de Freitas Filho ${ }^{2}$
}

\begin{abstract}
Resumo
Objetiva tecer análise crítica à Lei Complementar n‥ 24/75 sob a luz do Estado Democrático brasileiro, que reconheceu de forma ostensiva a democracia como pedra angular da República Federativa do Brasil. Inicia-se trazendo apontamentos preliminares acerca do sistema jurídico-tributário nacional, abordando e delimitando as normas jurídicas e a hierarquia que existe entre elas. Nesta linha, aduz sobre 0 papel desempenhado pela Constituição como diploma fundamental, notadamente em matéria tributária, esclarecendo, ainda, a função que tem a lei complementar neste contexto. Observa a influência do princípio democrático na estruturação do Estado brasileiro, traçando, após, considerações resumidas acerca do imposto sobre operações relativas à circulação de mercadorias. Examina as normas gerais disciplinadoras do tributo em apreço, com especial ênfase à Lei Complementar $n$ 은 24/75, que dispõe sobre a celebração de convênios para concessão de isenções e benefícios fiscais. Finalmente, analisa o contraste existente entre as exigências contidas na última e o preceito fundamental da democracia, adotado no Estado brasileiro.
\end{abstract}

Palavras-chave: Lei Complementar no 24/75; ICM S; Convênios; Democracia.

\section{Introdução}

Alicerçado em pesquisa bibliográfica de doutrina pátria, observando a legislação nacional correlacionada e utilizando o método analítico, o presente trabalho tem por escopo analisar, de forma crítica, a Lei Complementar no 24/1975 à luz do Estado democrático de direito brasileiro. 0 aventado diploma traz normas nacionais gerais acerca das isenções, benefícios e demais incentivos fiscais concedidos pelos Estados federados e pelo Distrito Federal no que atina ao imposto sobre operações relativas à circulação de mercadorias e sobre serviços de transporte interestadual e intermunicipal e de comunicação, operações e

${ }^{1}$ Discente do curso de Direito da Universidade Estadual de Londrina. Estagiário do Ministério Público Federal em Londrina/PR. Participante do Programa de Iniciação Científica da UEL.

${ }^{2}$ Discente do curso de Direito da Universidade Estadual de Londrina. Estagiário do Tribunal de Justiça do Paraná - comarca de Londrina. Bolsista do Conselho Nacional de Desenvolvimento Científico e Tecnológico (CNPq) no Programa de Iniciação Científica da UEL.

ReVISTA de DiReITo PúBLICO, LONDRINA, V, 4, N. 3, P. 50-70, SET./ DEZ. 2009. 
serviços estes inclusive provenientes do exterior (ICMS), disciplinado pela Constituição Federal no inciso II de seu artigo 155.

Neste passo, a Lei Complementar em exame dispõe sobre os convênios exigidos para viabilizar as referidas proficuidades em favor do contribuinte, assunto a ser ventilado neste estudo.

Preliminarmente, então, são feitos comentários propedêuticos acerca do sistema jurídico-tributário vigente no cenário brasileiro, momento em que são trazidas noções, ainda que de forma perfunctória, sobre normas jurídicas, sua divisão em estruturais e de comportamento, bem como a hierarquização existente. Aborda-se o papel desempenhado pela Constituição como diploma fundamental e inafastável, apontando-se o destaque que detém no que concerne às normas tributárias, sendo reservado espaço, ainda, para breve análise às normas gerais e à função que tem a Lei Complementar neste contexto.

Em momento posterior, ventila-se a influência do princípio democrático na estruturação do Estado brasileiro e da sociedade que o compõe. Abordam-se os contornos conceituais deste preceito fundamental, sua localização constitucional e as implicações que advém de sua adoção constitucional para a regência da sociedade.

Após, traçam-se breves considerações acerca do imposto sobre operações relativas à circulação de mercadorias, valendo-se de corte metodológico a fim de deixar de lado as hipóteses de incidência relativas à prestação de serviços de transporte interestadual e intermunicipal e de comunicação, bem como às situações relacionadas à prática de importação em que incide a modalidade tributária em comento. Assim, sem qualquer pretensão de se exaurir 0 assunto, são trazidas noções sobre 0 imposto, seu histórico, legislação regente e os critérios contidos na regra-matriz de incidência do mesmo, deixando de lado as problemáticas doutrinárias e jurisprudenciais existentes por não constituirem o mote desta pesquisa.

No capítulo seguinte, são trazidas à colação as Leis Complementares disciplinadoras deste imposto: as Leis $n=24 / 75$ e $n=87 / 96$, com especial ênfase a primeira, dada a pertinência temática existente com este trabalho.

Por fim, no último capítulo, em que se localiza a problemática principal, coloca-se 0 conflito entre o princípio democrático, com as implicações que dele emanam, e a Lei 
Complementar no 24/75, no que atina às exigências relativas à concessão de isenções e benefícios fiscais.

\section{Apontamentos propedêuticos acerca do sistema tributário brasileiro}

Analogicamente ao português, como é evidenciado por Gomes Canotilho (2003), o sistema jurídico do Estado de direito democrático brasileiro é um complexo normativo aberto de regras e princípios, uma vez que é um conjunto dinâmico de normas, que "tem uma estrutura dialógica, traduzida na disponibilidade e capacidade de aprendizagem das normas constitucionais para captarem a mudança da realidade e estarem abertas às concepções cambiantes da verdade e da justiça" (CANOTILHO, 2003, p. 1.160).

Consoante preconizado pela melhor doutrina (CANOTILHO, 2003), o superconceito norma engloba as subespécies regra e princípio, o que equivale a dizer que a norma se revela sob uma das duas formas explicitadas.

Desta forma, a todo momento, as normas jurídicas são construídas pelo hermeneuta segundo seu princípio unificador: a Constituição da República Federativa do Brasil, fundamento último de validade de qualquer outra norma positivada nos limites do território nacional (CARVALHO, 2008). Assim, para que uma norma seja reputada válida e, consectariamente, eficaz, é essencial que seja, em última análise, consentânea com os ditames preconizados pela Lex Fundamentalis. Uma vez que esteja em desacordo com a principiologia constitucional, a norma de escalão inferior deve ser expungida do ordenamento jurídico (LENZA, 2005), por desrespeito ao diploma supremo, dotado de força normativa (HESSE, 1991), inclusive, que é a Constituição.

Assim, a norma contrária a Constituição pode por ela não ser recepcionada, quando criada sob a ordem constitucional antecedente, como pode, além disso, demandar a necessidade de declaração de sua inconstitucionalidade (LENZA, 2005), para que seja tornada sem efeito, intra partes ou erga omnes, conforme o modo de controle de constitucionalidade utilizado - difuso ou concentrado, respectivamente, comentários aos quais, entretanto, não cabem maiores digressões no presente feito (SILVA, 1998).

Exsurge, então, o Direito Positivo: plexo de normas jurídicas vigentes e válidas em espaço territorial demarcado e em um determinado intervalo de tempo. As referidas normas que o integram, como insinuado, obedecem, na lição de Hans Kelsen (1987) a um 
escalonamento, formando o que 0 autor vienense entendeu por bem traduzir sob a forma de uma pirâmide, encontrando-se em seu apíce a Constituição, forjada conforme os anseios do povo que compõe a sociedade a ser por ela regida (KELSEN, 1987). Quanto maior a amplitude e a generalidade da norma, em maior plano ela se encontra, de sorte que as normas com menor grau de abstração e abrangência, com hierarquia inferior, devem se submeter às primeiras.

Exemplifica-se 0 exposto por meio da relação entre as denominadas normas de estrutura e as normas de comportamento. As primeiras detêm maior grau de abrangência na medida em que dispõem sobre as condições e modos procedimentais a serem observados para a produção escorreita e válida das últimas (CARVALHO, 2002), que são as regras, aludidas anteriormente, as quais podem ser reputadas como padrões de comportamento impostos aos seres humanos - prescrevendo "imperativamente uma exigência [...] que é ou não cumprida" (CANOTILHO, 2003, p. 1.161) - e, ao menos aprioristicamente, em benefício dos mesmos, considerando-se que objetivam viabilizar a vida em sociedade (LEAL JÚNIOR, 2009).

As normas de estrutura, portanto, destinam-se aos sujeitos autorizados a produzir as demais normas do ordenamento jurídico, ao passo que as de comportamento são aquelas produzidas pelo legislador, seguindo as prescrições estruturais genéricas, destinando-se imediatamente aos cidadãos e às pessoas jurídicas, eis que disciplinam suas condutas, no plano da vida, em permitidas, proibidas e obrigatórias (CARVALHO apud CARRAZA, 2004).

0 direito tributário positivo, como vértice jurídico, segue as premissas gerais até então expendidas, caracterizando-se, segundo o escólio do professor Paulo de Barros Carvalho $(2002$, p. 15), por ser o ramo didaticamente autônomo do direito, composto pelo "conjunto das proposições jurídico-normativas que correspondam, direta ou indiretamente, à instituição, arrecadação e fiscalização de tributos".

Neste passo, tem-se o Sistema Constitucional Tributário brasileiro como o conjunto de elementos e normas que envolvem o direito tributário pátrio. Geraldo Ataliba (1966) averba que, como qualquer sistema, o Sistema Tributário Nacional é composto por princípios somados a outros elementos, tais como regras, embora sejam aqueles que dêem sentido ao conjunto. 
Cassone (apud SILVA, 2009, p. 18) conceitua o sistema jurídico-tributário como o feixe de normas

que define as competências tributárias, impõe as limitações ao poder de tributar, regula a forma mediante a qual serão instituídos, exigidos e exonerados os tributos e impõe as penalidades decorrentes da não observância dos comandos legislativos que orientam a relação tributária.

No Brasil, por força da redação do artigo 1 o da Constituição, adota-se a forma federativa ${ }^{3}$ de Estado, o que implica, destarte, a formação de uma união institucional de Estados, que dá lugar ao Estado Federal, diverso dos que dele participam (os Estadosmembros). Assim, tem-se a federação brasileira, formada pela União, Estados, Municípios e Distrito Federal, de acordo com o indigitado dispositivo constitucional (CARRAZA, 2004), cada um deles dotado de autonomia legislativa, administrativa e financeira.

0 enfoque neste princípio é relevante haja vista que gera implicações para o Sistema Tributário Nacional, porquanto a aludida autonomia abrange também o campo tributário. Neste particular, dispõe o artigo 145 da Constituição que aos acenados entes federados cabe instituir determinados e específicos tributos, seguindo a senda percorrida pelo artigo 24 do mesmo diploma, que afirma competir "à União, aos Estados e ao Distrito Federal legislar concorrentemente sobre [...] direito tributário [...]".

Uma vez que os entes políticos detêm autonomia própria, as leis federais, estaduais, distritais e municipais têm, cada qual, sua parcela de competência própria, com atribuição peculiar, relativa a seu território, de sorte que uma não pode se sobrepor à outra, por não haver relação de hierarquia entre elas (CARRAZA, 2004). Por outro lado, para que sejam tidas por válidas, devem todas respeito à Constituição.

Como pode se observar, a autonomia dos entes políticos é consectário natural do Estado Federativo. Objetivando o pleno respeito a este modelo estatal, a Constituição atribuiu à União, ainda, a elaboração de normas nacionais, as quais diferenciam-se das federais por terem caráter geral a ponto de não só obrigar ao povo, mas, também, aos demais entes políticos, sendo o mecanismo encontrado para que seja estabelecido equilíbrio e convivência harmônica entre eles (CARRAZA, 2004).

3 É importante ressaltar que a federação brasileira é indissolúvel e que tal comando não comporta alteração, por compor cláusula pétrea, consoante lembra Roque Antonio Carrazza (2004). Para que seja abolido, no Brasil, é necessária a criação de uma nova ordem constitucional. 
Desta feira, conclui-se que estas normas nacionais encerram exatamente exemplos das mencionadas normas de estrutura, uma vez que visam complementar os comandos constitucionais, dispondo sobre a produção de outras normas por qualquer dos entes federados e dirimindo, com isso, conflitos de competência, especialmente em matéria tributária.

O veículo das normas nacionais, de acordo com o artigo 146 da Constituição, é a Lei Complementar, prevista no artigo 59, II, do mesmo diploma. No que respeita ao Sistema Tributário Nacional, têm por mote, além de tratar de conflitos de competência porventura existentes, regular as limitações constitucionais ao poder de tributar e estabelecer, como já sustentado, normas gerais em matéria de legislação tributária (AM ARAL, 2008).

A inserção do instituto da Lei Complementar na conjuntura pátria deve-se ao fato de ter o legislador constituinte verificado que, diante de sua natureza, não seria conveniente que determinadas matérias ficassem submetidas à rigidez constitucional, tampouco à flexibilidade concedida à legislação ordinária. Previu, em razão disso, a edição de normas integradoras do texto supremo, idôneas a orientarem, com força vinculante, o labor legislativo ordinário (AM ARAL, 2008).

É de suma importância, assim, o papel desempenhado pelas Leis Complementares ao criar normas gerais em matéria tributária, já que têm por nota fundamental a capacidade de integrar a legislação ordinária dos entes federativos às disposições constitucionais, representando a vontade "da própria Federação em seu todo considerada" (AM ARAL, 2008, p. 79).

Logo, as questões relativas às competências tributárias, as quais já encontram-se expressamente tratadas pela Constituição, devem ser pormenorizadas por normas gerais, veiculadas sob a forma de Lei Complementar.

Por fim, cabe relembrar que, devido a importância que têm os assuntos tributários, no Brasil, os mesmos são tratados, em linhas gerais, todos pela Carta Magna. Neste sentido, tem-se que as acenadas competências tributárias de cada um dos entes políticos estão delineadas no texto constitucional, não podendo sofrer qualquer alteração por emenda constitucional ou disciplina diversa por norma infraconstitucional. Assim sendo, por estarem insertos na Constituição, estes temas são cercados por uma rigidez peculiar, emanando comandos isonomicamente sobre todo o território nacional, cabendo às Leis 
Complementares integrarem estas prescrições de âmbito nacional, a fim de se obter harmonia federativa no sistema tributário pátrio.

\section{Da influência do Princípio democrático na estruturação do estado e da sociedade brasileira}

Analogicamente ao português, como é evidenciado por Gomes Canotilho, o sistema jurídico do Estado de direito democrático brasileiro é um complexo normativo aberto de regras e princípios, uma vez que é um conjunto dinâmico de normas, que "tem uma estrutura dialógica, traduzida na disponibilidade e capacidade de aprendizagem das normas constitucionais para captarem a mudança da realidade e estarem abertas às concepções cambiantes da verdade e da justiça" (CANOTILHO, 2003).

Consoante preconizado pela melhor doutrina (CANOTILHO, 2003), o superconceito norma engloba as subespécies regra e princípio. Ou seja, a norma se revela sob uma das duas formas explicitadas. Desta feita, imperioso se ostenta trazer à colação a definição dos termos sub examine.

É norma determinado preceito que tutela "situações subjetivas de vantagem ou de vínculo" (SILVA, 1998). Reconhece, por um lado, a pessoas ou entidades, a faculdade de realizar dados interesses por ato próprio ou exigindo ação ou abstenção de outrem, e, em contrapartida, vincula pessoas ou entes ao dever de se submeter às exigências de realizar certa prestação, positiva ou negativa, em favor de terceiro (SILVA, 1998).

Regra jurídica, de seu turno, pode ser reputada como padrão de comportamento imposto aos seres humanos - prescrevendo "imperativamente uma exigência [...] que é ou não cumprida" (CANOTILHO, 2003) - e, ao menos aprioristicamente, em benefício dos mesmos, considerando-se que objetiva viabilizar a vida em sociedade. Esgota-se em si mesma, na medida em que descreve "o que se deve, não se deve ou se pode fazer em determinadas situações [...]" (ZAGREBELSKY apud M ARIONI, 2001). Tem, a priori, e de forma contrária aos princípios, aplicabilidade imediata e seu grau de abstração, outrossim, não é tão elevado quanto o daqueles (CANOTILHO, 2003).

0 termo princípio, finalmente, originário do latim principium, principii (CARRAZA, 2007), em linguagem leiga, traduz a idéia de origem, início, base, ponto de partida (DINAM ARCO, 2001). Abordada por Kant (CARRAZA, 2007), a palavra em comento foi 
tomada como toda proposição geral que pode servir como premissa maior em um silogismo. A referida expressão, dessarte, equivale à pedra angular de dado sistema. Neste sentido, esclarecedora é a lição de Geraldo Ataliba (1966), na qual encontra-se averbado que o último é composto por princípios somados a outros elementos, embora sejam aqueles que dêem sentido ao conjunto. Ainda, pontifica que, quanto menor for o número de princípios, mais perfeito será o sistema que eles integram.

Ingressando no âmbito do Direito, entende-se princípio jurídico como "um enunciado lógico, implícito ou explícito, que, por sua grande generalidade, ocupa posição de preeminência nos vastos quadrantes do Direito" (CARRAZA, 2007) e, por tal razão, vincula, de modo indeclinável, a exegese e a aplicação das normas jurídicas que com ele se conectam. São tidos como o "conjunto de regras ou preceitos que se fixaram para servir de norma à toda espécie de ação jurídica, traçando, assim, a conduta a ser tida em qualquer operação jurídica" (SILVA, 1967). Revelam-se a própria essência das coisas afetas ao direito, transmutando-se em verdadeiros axiomas. Na definição lapidar de Celso Antônio Bandeira de M ello (1993) é princípio a

disposição fundamental que se irradia sobre diferentes normas, compondo-lhes 0 espírito e servindo de critério para a sua exata compreensão e inteligência, exatamente por definir a lógica e a racionalidade do sistema normativo, no que Ihe confere a tônica e the dá sentido harmônico. É o conhecimento dos princípios que preside a intelecção das diferentes partes componentes do todo unitário que há por nome sistema jurídico positivo.

Assentada a definição de princípio jurídico, impende afirmar que esse não é concebível em estado de isolamento: apresenta-se sempre relacionado com outros princípios e demais elementos, formando um todo concatenado que alveja a manutenção de um status harmônico. Assim, leciona Carraza (2007) que os princípios são encontráveis por toda a estrutura da pirâmide jurídica, havendo de ordem constitucional, legal e, até mesmo, infralegal.

Neste passo, é mister delinear os aludidos princípios constitucionais, também intitulados jurídico-constitucionais. Tais podem ser entendidos como as normas mais gerais existentes em determinado sistema jurídico. Por mais generalidade que detenham, não deixam de ter caráter normativo, como bem demonstrara Bobbio (1989) outrora. Assim se 
coloca vez que os princípios constitucionais tem o mesmo fito que as normas expressas, qual seja, regular comportamentos humanos.

Desta feita, por serem normas e por deterem amplitude maior, sendo, então, os pontos de apoio normativo para a eficiente aplicação do Direito (DINAM ARCO, 2001), aos princípios jurídico-constitucionais deve haver estrita observância, já que sua infringência implica consequências mais gravosas ao sistema do que a desobediência de simples regra, mesmo que de ordem constitucional. E dentre os princípios constitucionais, há ainda a categoria dos princípios-garantia, normas de direitos fundamentais que visam de forma direta e imediata instituir garantias aos cidadãos ${ }^{4}$.

Para a solução de problemas jurídicos, o operador do Direito deve, preliminarmente, lançar mão dos princípios constitucionais, na busca de orientação interpretativa, sendo forçoso assentar, aqui, ser a interpretação atividade cognoscitiva que tem por mote precisar a significância e o alcance das normas, viabilizando, assim, sua adequada aplicação.

Assim, conjuntamente, os princípios traduzem a ideologia da Magna Carta (BARROSO, 1998), orientando, iluminando e condicionando a exegese das normas jurídicas em geral. Impraticável a hermenêutica que afronte princípios desta ordem, exceto se estiver em concordância com outro de valor, naquele caso, superior, como se demonstrará a posteriori neste trabalho.

Nesta vereda, sublinha-se que princípios antinômicos podem coexistir5, diferentemente de regras contraditórias, as quais, necessariamente, excluem-se, haja vista ser insustentável sua validade simultânea. Ademais, a regra é ou não obedecida, ao passo que o princípio possui inúmeros graus de concretização, que variam em razão de condicionalismos fáticos e jurídicos. Alexy (2001) esclarece que "la distinción entre reglas y principios constituye, además, el marco de una teoría normativo-material de los derechos fundamentales".

Jesús González Perez (apud CARRAZA, 2007) estatui que os princípios constituem a parte estável e perene do Direito, ao mesmo tempo em que compõem, como sublinhado alhures, o fator cambiante e mutável que proporciona a evolução jurídica. Traduzem os

\footnotetext{
${ }^{4}$ Como exemplo, o princípio do juiz natural, o do devido processo legal e o da razoável duração do processo, a ser esmiuçado no quinto capítulo.

${ }^{5} \mathrm{O}$ que será sublinhado posteriormente.
} 
ideais basilares e informadores da organização jurídica nacional, de sorte que todo o direito positivo, consoante definido pelo Superior Tribunal Federal ${ }^{6}$, deve se encontrar em consentâneo com os princípios de ordem constitucional.

Insta repisar, por derradeiro, lembrando Hesse (1991), que os princípios apontam a aspiração da Lex Fundamentalis, sendo que essa deve ser, na totalidade das vezes, preservada, diante de sua insofismável "força normativa", tendo em vista que o Direito Constitucional, inegavelmente, integra o direito positivo. Mais do que guia interpretativo, importa lembrar, ainda, o feixe principiológico constitucional vincula o legislador no momento da elaboração de diplomas, ficando sua discricionariedade adstrita aos ideais insculpidos nos princípios jurídicos gerais.

\section{Breves considerações acerca do imposto sobre operações relativas à circulação de mercadorias}

Por meio da Emenda Constitucional no. 18, de 10 de dezembro de 1965, modificadora da Carta de 1946, que realizou intensa reforma tributária, surgiu o ICM S no Sistema Tributário Nacional, com a denominação de "imposto sobre operações relativas à circulação de mercadorias, realizadas por comerciantes, industriais e produtores" (ICM), em substituição ao "imposto sobre vendas e consignações efetuadas por comerciantes e produtores, inclusive industriais" (IVC), criado com o advento do diploma constitucional de 1934, já que este não era economicamente vantajoso.

Com a promulgação do Código Tributário Nacional (CTN) em 1966, o ICM foi incluído na categoria de Impostos so bre a Produção e a Circulação.

0 imposto, quando de sua instituição, teve expressamente excluídas de sua faixa de incidência certas mercadorias, as quais foram imputadas ao campo de tributação da União: lubrificantes, combustíveis líquidos ou gasosos, energia elétrica e minerais.

Com a Constituição da República Federativa do Brasil de 1988, a ressalva deixou de existir. Passou 0 imposto a abranger também as referidas mercadorias, além de agasalhar 0

\footnotetext{
${ }^{6}$ Durante o julgamento da Ação Direta de Inconstitucionalidade 319-4-DF, com decisão publicada no DJU em 30.04.93.

7 Já afirmada anteriormente, por meio dos ensinamentos de Bobbio.
} 
objeto "serviços", complementando o verbo-núcleo "circular", constituindo o ICMS a principal fonte de arrecadação de receitas dos Estados e do Distrito Federal.

O aludido IVC, instituído na lei magna de 1934 e mantido na de 1946 até 0 advento da alteração supramencionada, incidia exclusivamente sobre as operações de vendas e consignações. Assim, "tinha sua incidência estritamente vinculada à figura jurídica da venda mercantil, e não a fatos econômicos propriamente ditos", razão pela qual "não esgotava a série de casos representativos da circulação de riquezas" (REIS; BORGES, 1992).

De toda sorte, o surgimento de imposto não incidente sobre o patrimônio dos cidadãos constituiu novidade à época.

O IVC era cumulativo: não se procedia ao abatimento de créditos referentes a operações anteriores, o que era tido pela doutrina como deformidade. A técnica buscada foi a de onerar tão-somente o valor acrescido. Assim adveio o ICM, que já de inicio prestigiava a não-cumulatividade e tinha como interessante característica a uniformidade de alíquotas para todas as mercadorias (REIS; BORGES, 1992).

Ademais, da análise do texto da Emenda Constitucional no 18, de 1ㅇ de dezembro de 1965, nota-se que podiam os Municípios arrecadar o ICM nas operações realizadas dentro de seu território, com base na legislação estadual respectiva e por alíquota não superior a $30 \%$ da instituída pelo Estado ${ }^{8}$. Entretanto, notou-se inviabilidade dos M unicípios quanto a isso, o que culminou na edição do Ato Complementar no 31, de 28 de dezembro de 1966, o qual, em substituição à competência para arrecadar o ICM , conferiu aos Municípios participação de $20 \%$ no produto de sua arrecadação ${ }^{9}$.

\footnotetext{
${ }^{8}$ Redação original:

"Art. 13. Compete aos Municípios cobrar o impôsto referido no artigo com base na legislação estadual a ele relativa, e por alíquota não superior a 30\% (trinta por cento) da instituída pelo Estado.

Parágrafo único: A cobrança prevista neste artigo é limitada às operações ocorridas no território do Município, mas independente da efetiva arrecadação, pelo Estado, do impôsto a que se refere o artigo anterior [sic]."

${ }^{9}$ A destinação de parcela da receita do ICMS aos municípios é assegurada pela Constituição. Conforme o artigo 158, "pertencem aos Municípios: [...] IV - vinte e cinco por cento do produto da arrecadação do imposto do Estado sobre operações relativas à circulação de mercadorias e sobre prestações de serviços de transporte interestadual e intermunicipal e de comunicação". Prossegue o parágrafo único:

"As parcelas de receita pertencentes aos Municípios, mencionadas no inciso IV, serão creditadas conforme os seguintes critérios:

I - três quartos, no mínimo, na proporção do valor adicionado nas operações relativas à circulação de mercadorias e nas prestações de serviços, realizadas em seus territórios;

II - até um quarto, de acordo com o que dispuser lei estadual ou, no caso dos Territórios, lei federal."
} 
Enfim, chega-se, com a promulgação da "Constituição Cidadã", ao ICMS, imposto plurifásico (que incide sobre todas as fases de circulação da mercadoria), não cumulativo ${ }^{10}$ (de forma que cabe compensação em cada operação ou prestação de serviços do valor pago nas operações anteriores) e seletivo ${ }^{11}$ em função da essencialidade das mercadorias e serviços.

A incidência plural já existia desde o IVC. A novidade (presente, em verdade, desde o ICM) estava contida especialmente na não-cumulatividade, isto é, nos abatimentos dos valores pagos na circulação precedente. Tal característica teve por inspiração o tributo taxe sur la valeur ajountée, adotado na França em 1954, o qual também observava o princípio da não-cumulação.

Carrazza (2007) considera-o, ainda, um imposto indireto, eis que admite transferência do encargo mediante o fenômeno da repercussão. Com base nesta última característica, a doutrina divide a figura do contribuinte em de direito e de fato, sendo 0 primeiro "a pessoa física ou jurídica que tem o dever assinalado por lei a pagar tributo, dada a sua relação pessoal e direta com o respectivo fato gerador". No ICMS, é o comerciante, o produtor, o industrial e o prestador de serviços. 0 segundo é "aquele que arca efetivamente com o ônus do imposto, embora sem ter o dever assinalado por lei de fazê-lo. Desse modo, [...] é o consumidor final", conforme preleciona Maria Lúcia Américo dos Reis e José Cassiano Borges (1992).

0 imposto em comento encontra-se previsto no texto constitucional no inciso II do artigo 155, que, em sua redação atual, preceitua o seguinte:

Art. 155. Compete aos Estados e ao Distrito Federal instituir impostos sobre: [...] II operações relativas à circulação de mercadorias e sobre prestações de serviços de transporte interestadual e intermunicipal e de comunicação, ainda que as operações e as prestações se iniciem no exterior [...].

Diante da previsão constitucional, reputa-se atécnica a conceituação do tributo em estudo como "imposto sobre circulação de mercadorias e serviços" pura e simplesmente.

${ }_{10}$ Assim consigna o inciso I do § 20 do artigo 155 da Constituição: "será não-cumulativo, compensando-se 0 que for devido em cada operação relativa à circulação de mercadorias ou prestação de serviços com 0 montante cobrado nas anteriores pelo mesmo ou outro Estado ou pelo Distrito Federal".

${ }^{11} \mathrm{O}$ que dispõe 0 inciso III do mesmo § 2 ㅇ: "poderá ser seletivo, em função da essencialidade das mercadorias e dos serviços". 
Cuida-se, em verdade, de "imposto sobre operações relativas à circulação de mercadorias e sobre prestações de serviços de transporte interestadual e intermunicipal e de comunicação", como propõe a doutrina mais abalizada, já que é esta a indicação constitucional.

Roque Antonio Carraza (2001) tece comentários acerca da hipótese de incidência do ICMS:

A sigla ICMS alberga pelo menos cinco impostos diferentes; a saber: a) o imposto sobre operações mercantis (operações relativas à circulação de mercadorias); b) 0 imposto sobre serviços de transporte interestadual e intermunicipal; c) o imposto sobre serviços de comunicação; d) o imposto sobre produção, importação, circulação, distribuição ou consumo de lubrificantes e combustíveis líquidos e gasosos e de energia elétrica; e, e) o imposto sobre a extração, circulação, distribuição ou consumo de minerais.

E afirma que se dizem diferentes porque estes tributos têm hipóteses de incidência e bases de cálculos distintas.

Tem-se que o próprio texto constitucional, no artigo 155, II, indica o campo de incidência ao autorizar os Estados e o Distrito Federal a instituir, dentro de seus respectivos territórios, imposto sobre: circulação de mercadorias; prestações de serviços de transporte interestadual e intermunicipal e serviços de comunicação.

Em interpretação sistemática, observa-se que a Constituição autoriza aos entes federados, por meio de lei complementar, "estabelecer normas gerais em matéria de legislação tributária, especialmente sobre [...] definição de tributos e de suas espécies, bem como, em relação aos impostos discriminados nesta Constituição, a dos respectivos fatos geradores, bases de cálculo e contribuintes" ${ }^{\prime 12}$.

Referida lei complementar terá por fito delinear, de forma mais detalhada, o campo de incidência autorizado pela Constituição. No caso do ICM , criado pela Emenda no. 18/65, foi o Decreto-Lei $406 / 68$, reputado com força de lei complementar ${ }^{13}$. Posteriormente, o Convênio 66/88, amparado pelo artigo 34, § 8으, do Ato das Disposições Constitucionais Transitórias, desenvolveu esta missão até a data do dia 13 de setembro de 1996, momento

\footnotetext{
${ }^{12}$ Artigo 146, III, a.

${ }^{13}$ Artigo 146, III, a.
} 
em que se promulgou a lei complementar $n \cong .87 / 96$, incumbida de desenvolver a aludida função.

Assim, tal lei, alcunhada de Lei Kandir reza, em seu artigo 2ํㅜ , que o ICM S incide sobre:

I - operações relativas à circulação de mercadorias, inclusive o fornecimento de alimentação e bebidas em bares, restaurantes e estabelecimentos similares;

II - prestações de serviços de transporte interestadual e intermunicipal, por qualquer via, de pessoas, bens, mercadorias ou valores;

III - prestações onerosas de serviços de comunicação, por qualquer meio, inclusive a geração, a emissão, a recepção, a transmissão, a retransmissão, a repetição e a ampliação de comunicação de qualquer natureza;

IV - fornecimento de mercadorias com prestação de serviços não compreendidos na competência tributária dos M unicípios;

$\mathrm{V}$ - fornecimento de mercadorias com prestação de serviços sujeitos ao imposto sobre serviços, de competência dos Municípios, quando a lei complementar aplicável expressamente o sujeitar à incidência do imposto estadual.

$0 \S 10$ prossegue declarando que o imposto incide também:

I - sobre a entrada de mercadoria ou bem importados do exterior, por pessoa física ou jurídica, ainda que não seja contribuinte habitual do imposto, qualquer que seja a sua finalidade;

II - sobre o serviço prestado no exterior ou cuja prestação se tenha iniciado no exterior;

III - sobre a entrada, no território do Estado destinatário, de petróleo, inclusive lubrificantes e combustíveis líquidos e gasosos dele derivados, e de energia elétrica, quando não destinados à comercialização ou à industrialização, decorrentes de operações interestaduais, cabendo o imposto ao Estado onde estiver localizado o adquirente.

Esta lei, no entanto, não obriga os Estados e o Distrito Federal a cobrar e/ou arrecadar o ICMS. Para isso, é mister lei estadual (ou distrital) respectiva nesse sentido, instituindo o imposto (CARRAZA, 2007).

O objetivo da lei complementar em apreço é, portanto, definir e detalhar os fatos que o legislador estadual poderá adotar na descrição das hipóteses de incidência deste. Isto quer dizer que se não houver lei estadual não existirá o imposto. Nenhum Estado poderá cobrar o ICM S se a sua Assembléia Legislativa não houver instituído esse imposto, editando a lei para esse fim necessária. Por outro lado, o legislador estadual não pode definir como hipótese de incidência do ICMS algo que não esteja previsto na lei complementar como 
âmbito de sua atuação, como campo no qual esse legislador pode operar na definição da hipótese de incidência do imposto.

\section{Regra-matriz de incidência do Icm}

Dispensando-se explicações acerca da natureza da regra-matriz geral, no Direito Tributário, o corrente subtópico analisa, de forma breve, os elementos atinentes ao ICM abstendo-se de discorrer sobre a questão dos "serviços", seguindo corte metodológico já exposto na introdução do presente trabalho.

Analisar a regra-matriz de incidência de um determinado tributo é desenvolver estudos referentes às situações que conduzem um sujeito à obrigação de recolher o quantum devido ao Fisco, norteando-se por seus critérios material, espacial, temporal, quantitativo e pessoal. O professor Paulo de Barros Carvalho (2002) leciona no seguinte sentido:

A norma tributária, em sentido estrito, reiteramos, é a que define a incidência fiscal. Sua construção é obra do cientista do Direito e se apresenta, de final, com a compostura própria dos juízos hipotético-condicionais. Haverá uma hipótese, suposto ou antecedente, a que se conjuga um mandamento, uma conseqüência ou estatuição.

0 artigo 155, II, da Constituição Federal estabelece o critério material do ICM; depreende-se, dessa forma, que este abrange as operações relativas à circulação de mercadorias, bem como as operações de importação de mercadorias do exterior. Por circulação de mercadorias deve ser entendida a transferência de propriedade, ou seja, compra e venda ${ }^{14}$.

Já o critério espacial do ICM é deveras peculiar, pois seu caráter é nacional, o que garante sua incidência em todo o território da União; entretanto, é necessária a individualização das operações, observando-se a competência territorial de cada ente federado (e regime de não-cumulatividade) para cobrá-lo. Em linhas gerais, pode ser dito que para identificação do critério espacial do ICM toma-se como local de realização da operação o estado do estabelecimento que alienou a mercadoria.

\footnotetext{
${ }^{14}$ Ainda que não haja transferência de titularidade, há a incidência de ICM na transferência de mercadorias entre estabelecimentos de uma mesma empresa, caso localizem-se em diferentes estados da federação, de acordo com Súmula do ST].
} 
Sendo o critério temporal o momento em que o fato jurídico ocorre (e torna-se, conseqüentemente, tributável), o ICM incide sobre as mercadorias no momento em que estas deixam o estabelecimento alienante.

0 critério quantitativo é composto por dois elementos, quais sejam, a base de cálculo e a alíquota. Aquela é composta, em princípio, o valor da mercadoria devidamente constante em sua nota-fiscal, atentando-se aos acréscimos legais e à não-cumulatividade. A alíquota, de seu turno, é estipulada pelos estados, com relação à circulação de mercadorias dentro de seu território, e pelo Senado, atinente às circulações entre diferentes estados. Sua variação ocorre conforme a base de cálculo, a operação e a mercadoria (seletividade da alíquota).

No que tange ao critério pessoal, o ICM tem os estados federados e o Distrito Federal como seus sujeitos ativos, observando-se a disposição constitucional que concede aos mencionados entes a competência para cobrança do tributo em comento. A sujeição passiva, por sua vez, recai, nos termos da Lei $n^{\circ} 87 / 96$, sobre pessoas físicas ou jurídicas que pratiquem atos de circulação de mercadorias com finalidade de lucro e habitualidade - 0 que caracteriza a atividade mercantil.

\section{Do conflito entre a lei complementar $n^{\circ} 24 / 75$ e o princípio da democracia}

A elaboração do Código Tributário Nacional em 1966, sob o manto de outro texto constitucional, teve como conseqüência a não-compreensão, por tal codex, de determinados temas mencionados no artigo $146^{15}$ da Constituição Federal em vigência, promulgada em 1988. Neste particular, o aludido Código é omisso no que respeita às regras necessárias à composição de eventual conflito de interesses entre as unidades federadas, não cuidando da denominada "guerra fiscal".

No âmbito dos $\operatorname{Estados}^{16}$, a expressão quer significar a desenfreada luta por eles travada "para atraírem para seus respectivos territórios investimentos internos e externos capazes de promover o desenvolvimento industrial, comercial e social de suas regiões" (SILVA, 2009, p. 25). Os Estados, para tanto, valem-se de políticas tributárias, oferecendo concessões de isenções ou outras formas de incentivos fiscais, reduzindo, com isso, o custo

\footnotetext{
${ }^{15} \mathrm{O}$ inciso XII do § 2 o do artigo 155 contém exigência no mesmo sentido, mas especificamente quanto ao ICMS.

${ }^{16}$ Entenda-se, neste diapasão, abrangido o Distrito Federal.
} 
da produção, objetivando, em realidade, o aumento da arrecadação do imposto sobre operações relativas à circulação de mercadorias (SILVA, 2009). Essa disputa acaba por criar desarmonia e desproporção na sistemática tributária pátria, o que exige a adoção de mecanismos para evitar a guerra fiscal.

A existência da guerra fiscal no que respeita ao ICMS tem por causa a falta do devido tratamento sobre o tema pelo legislador nacional. 0 assunto requer a criação de lei complementar disciplinando-0, conforme se observa do texto constitucional.

Conforme já trazido no capítulo retro, no ano de 1996 foi editada a Lei Complementar no. 87, alcunhada de "Lei Kandir", em substituição ao Decreto-Lei no. 406/68, tendo por escopo atender à exigência contida no inciso XII do $\S 20$ do artigo 155 da Constituição. 0 referido dispositivo arrolou uma série de temas a serem regulados por Lei Complementar, os quais receberam tratamento da Lei Kandir, salvo 0 assunto contido em sua alínea g, isto é, "a forma como, mediante deliberação dos Estados e do Distrito Federal, isenções, incentivos e benefícios fiscais [relativos ao ICM S] serão concedidos e revogados".

Excluído do rol de temas disciplinados pela Lei Kandir, entende-se ainda hoje regulado pela Lei Complementar no. 24/75, recepcionada pela Constituição. Essa lei determina que as isenções e demais benefícios fiscais relativos ao ICMS serão concedidos ou revogados nos termos de convênios celebrados e ratificados pelos Estados e pelo Distrito Federal ${ }^{17}$.

Esses convênios são firmados no âmbito do Conselho Nacional de Política Fazendária (CONFAZ), integrado equitativamente por representantes de todos os Estadosmembros e do Distrito Federal. Celebram-se em reuniões para as quais tenham sido convocados representantes de todos os referidos entes políticos, sob a presidência do Governo federal, conforme o contido no caput do artigo 20 da mesma lei.

0 § 20 do artigo sobredito afirma que, para ser deferido pleito de concessão de benefício fiscal, exige-se decisão unânime dos Estados representados e do Distrito Federal. Com isso, verifica-se procedimento deveras diferenciado, já que nem mesmo a aprovação de emenda constitucional requer unanimidade de consenso, mas tão-só maioria qualificada. Evaldo de Souza da Silva (2009) anota que a lei em tela exige, ademais, a ratificação dos

\footnotetext{
${ }^{17}$ Artigo 10, caput.
} 
convênios (já aprovados pela integralidade dos representantes) por decreto específico em cada uma das unidades federadas, criando burocratização ainda maior.

A exigência de aprovação por todos os membros do CONFAZ choca-se com as diretrizes da democracia, em que se assentam as estruturas do Estado brasileiro. Pautar-se na democracia é obedecer à vontade da maioria, que, por sua vez, não é o mesmo que unanimidade.

Pelo que se verifica do artigo $1^{\circ}$ da Constituição Federal, o princípio da democracia é elemento central ao cenário jurídico-político brasileiro, garantindo a democracia representativa e direta, com a emanação de poder pelo povo, o que alicerça o Estado Democrático de Direito. Destarte, irrefutável é que o princípio da democracia é verdadeiro preceito fundamental do Estado brasileiro.

A razão para tal gritante incompatibilidade é a elaboração da lei complementar $n^{\circ}$ 24/75 sob a égide de texto constitucional diverso da Carta Constitucional atualmente vigente. Sobre o tema, Evaldo de Souza da Silva (2009) explica:

\begin{abstract}
Não se deve deslembrar que 0 fato de a Lei Complementar no 24/75 anteceder a promulgação da Constituição Federal não impede seja a mesma questionada em controle difuso, estando vedado, unicamente, o manejo de Ação Direta de Inconstitucionalidade para se obter tal desiderato, porquanto o Supremo Tribunal Federal firmou entendimento no sentido de que não é esse o remédio jurídico para questionar ato normativo anterior à promulgação da Constituição ou emenda que Ihe tenha sido imprimida.
\end{abstract}

A posição do Estado brasileiro ao admitir a dispensa do recolhimento de tributos, mediante acordo entre os entes envolvidos na relação jurídica, traduz a intenção de promover a redução das profundas disparidades sócio-econômicas arraigadas nas diferentes partes de seu território. Contudo, o que se observa nesse contexto é a produção de efeitos completamente opostos àqueles almejados por uma política tributária dos moldes brasileiros.

Desprezar o preceito fundamental da democracia é o mesmo que deixar de se preocupar com todos os demais objetivos fundamentais de um Estado Democrático de Direito, dando espaço à construção de comportamentos estritamente políticos, por parte dos entes federados. Ademais, a necessidade de ratificação do convênio, por todos os 
membros do CONFAZ, é óbice de grande magnitude ao combate à guerra fiscal, uma vez que se mostra procedimento extremamente moroso e, conseqüentemente, falho.

\section{Conclusão}

A instituição de convênios entre os estados federados tem por escopo conferir distribuição equânime das atividades econômicas pelo território nacional, mostrando-se instrumento extremamente válido à promoção do desenvolvimento sócio-econômico pátrio. Todavia, enxerga-se, claramente, a ineficiência deste mecanismo, que, detentor de grande potencial para encerrar as disputas entre entes federados, mostra-se mero componente da estrutura burocrática tributária nacional.

Exigir concordância unânime dos membros do CONFAZ para instituição de convênios entre estados, visando à isenção tributária, fere o preceito máximo da democracia, ao desprezar a vontade da maioria para buscar a vontade da totalidade. Assim, o posicionamento contrário de apenas um dos estados da federação impede a instituição de convênio para dispensa do recolhimento do tributo - proliferando a guerra fiscal sem qualquer método de controle.

Em razão de tamanha dificuldade para a celebração de tais convênios, acaba por se verificar na prática a desobediência do aludido regramento pela maioria dos Estados, o que, inexoravelmente, acarreta guerra fiscal, contexto que só prejudica a harmonia e o uniforme desenvolvimento da nação. Os efeitos observados no cenário econômico nacional são danosos aos entes federados menos favorecidos, que perdem as empresas instaladas em seus territórios para os entes mais abastados que concedem substanciais (e injustos) incentivos e isenções. A redução da oferta de emprego e a diminuição da movimentação de capital em determinadas regiões são apenas dois dos profundos impactos que a guerra fiscal gera no já desequilibrado contexto brasileiro.

O cerne da questão debatida no corrente trabalho está na atuação do Congresso Nacional, que se abstém de debater o conflito existente entre a lei complementar $n^{\circ}$. 24/75 e os pilares democráticos do Estado brasileiro.

Inquestionável é a faceta inconstitucional da mencionada lei, cabendo ser dito que 0 rito previsto em seu texto é latentemente antidemocrático ao ofender o preceito fundamental da democracia. Há que se lamentar o posicionamento (ou sua falta) do 
Congresso Nacional quanto ao controverso tema em pauta, preferindo despender tempo na reestruturação da política tributária nacional, no que concerne à arrecadação do ICM, em detrimento à reavaliação do mecanismo da já referida lei complementar.

A alteração da sistemática de instituição de convênios entre os entes federados mostra-se mais plausível ao funcionamento da política tributária nacional, que está em consonância às bases constitucionais, e objetiva a solidificação do Estado Democrático de Direito.

\section{Referências}

AM ARAL, Antonio Carlos Rodrigues do. Lei complementar. In: MARTINS, Ives Gandra da Silva (Coord.). Curso de Direito Tributário. 10. ed. São Paulo: Saraiva, 2008.

ATALIBA, Geraldo. Sistema Constitucional Tributário Brasileiro. São Paulo: Revista dos Tribunais, 1966.

BARROSO, Luís Roberto. Interpretação e aplicação da Constituição. 2. ed. São Paulo: Saraiva, 1998.

BOBBIO, Norberto. Teoria do Ordenamento Jurídico. Brasília: Polis, 1989.

CANOTILHO, José Joaquim Gomes. Direito Constitucional e Teoria da Constituição. 7. ed. Coimbra: Almedina, 2003.

CARRAZZA, Roque Antonio. Curso de Direito Constitucional Tributário. 23. ed. São Paulo: Malheiros, 2007.

. Curso de Direito Constitucional Tributário. 20. ed. São Paulo: Malheiros, 2004.

CARVALHO, Paulo de Barros. "Crédito de ICMS" e "crédito de indébito tributário": consequencias jurídicas desta distinção. Revista Jurídica Empresarial, Porto Alegre, n. 2, p. 147-172, maio/jun. 2008.

. Curso de Direito Tributário. 14. ed. São Paulo: Saraiva, 2002.

DINIZ, M aria Helena. Compêndio de introdução à ciência do direito. 17. ed. São Paulo: Saraiva, 2005.

FERREIRA, Luiz Pinto. Curso de Direito Constitucional. São Paulo: Saraiva, 1991.

FERREIRA FILHO, M anoel Gonçalves. Comentários à Constituição Brasileira de 1988. São Paulo: Saraiva, 1990. v.1. 
. Curso de Direito Constitucional. 17. ed. São Paulo: Saraiva, 1989.

HESSE, Konrad. A força normativa da Constituição. Porto Alegre: Sérgio Fabris, 1991.

KELSEN, Hans. Teoria pura do direito. 2. ed. São Paulo: Martins Fontes, 1987.

LEAL JÚNIOR, João Carlos. Análise crítica do duplo grau de jurisdição sob o prisma do direito à razoável duração do processo. 2009. Trabalho de Conclusão de Curso (Graduação em Direito) - Universidade Estadual de Londrina, Londrina, 2009.

LENZA, Pedro. Direito Constitucional Esquematizado. 8. ed. São Paulo: Método, 2005.

M ACHADO, Hugo de Brito. Curso de Direito Tributário. 25. ed. São Paulo: M alheiros, 2004.

M ELLO, Celso Antonio Bandeira de. Curso de Direito Administrativo. São Paulo: Malheiros, 1993.

SILVA, José Afonso da. Curso de Direito Constitucional Positivo. 15. ed. São Paulo: Malheiros, 1998.

SILVA, Evaldo de Souza da. 0 conflito entre a Lei Complementar no. 24/1975 e o princípio da democracia. Revista IOB de Direito Público, São Paulo, n. 29, p. 16-33, set./out. 2009.

REALE, M iguel. Lições preliminares de direito. 27. ed. São Paulo: Saraiva, 2004. 